Virgínia T. Schall 1,2

Simone Montei ro 2

Sandra M. Rebello 2

Maysa Torres 2

\section{Evaluation of the ZIG-ZAIDS game: an entertaining educational tool for HIV/Aids prevention}

\author{
Avaliação do J ogo ZIG-ZAIDS - um recurso \\ lúdico-educativo para informação e prevenção \\ da AIDS entre pré-adolescentes
}

1 Centro de Pesquisas René Rachou, Fundação Oswaldo Cruz. Av. Augusto de Lima 1715, Barro Preto, Belo Horizonte, MG 30190-002, Brasil. vtschall@cpqrr.fiocruz.br 2 Laboratório de Educação em Ambiente e Saúde, Departamento de Biologia, Instituto Oswaldo Cruz, Fundação Oswaldo Cruz (Centro colaborador da UNAIDS/WHO). Av. Brasil 4365, Manguinhos, Rio de Janeiro, RJ 21045-900, Brasil.
Abstract This article presents the evaluation process for the ZIG-ZAIDS game, investigating the material's applicability in formal and informal educational contexts, i.e., how the game has been used by health professionals, parents, and the target population (pre-adolescents, or children over 9 years old). The study involved evaluation questionnaires sent to a list of schools and institutions using the game, plus interviews and vi sits to places where the game was used as well astested with groups of students. It al so includes an analysis of evaluation previously sent by the authors to people who had requested the game. The results showed that the population's level of information is more relevant than age in relation to the game's impact. Another important aspect rel ates to ZIG-ZAIDS' applicability to different situations: training of health and teaching professionals; activities with street children; municipal institutions and events, schools, companies, communities, and heal th care centers. In summary, ZIG-ZAIDS was found to be an entertaining, creative, and innovative al ternati ve for providing information on AIDS and sexuality. Key words Health Education; Educational Technology; Evaluation of Results of Preventive Actions; Sex Behavior; HIV; Acquired Immunodeficiency Syndrome

Resumo Esteartigo apresenta o processo de avaliação de um material educativo, o jogo ZIGZAIDS, que teve por objetivo verificar a apl icabili dade deste material em espaços educacionais formais e informais, ou seja, investigar como vem sendo utilizado por profissionais e pais, epela população-alvo (pré-adolescentes). O estudo envolveu o envio de questionários de avaliação a escolas e institui ções que fazi am uso do jogo, entrevistas, visitas a al guns locais onde o jogo estava em uso e testagem com grupos de alunos. Incluiu ainda anál ise de avaliações enviadas anteriormente pelas autoras a sol i citantes do jogo. Os resultados demonstraram que o nível de informação da população é mais rel evante do quea idade em relação ao impacto do jogo. Outro aspecto destacado relaciona- se à apli cabilidade do ZIG-ZAIDS a situações di versas, como: em trei namentos de profissionais de ensino e saú de; em ati vi dades com menores que vivem na rua; em eventos de prefei turas e insti tuições, em escolas, empresas, comunidades e postos de saúde. Sintetizando, o ZIG-ZAIDS foi considerado uma alternativa lúdica, criativa e inovadora para informar sobreAIDSe sexualidade.

Palavras-chave Educação em Saúde; Tecnologia Educacional; Avaliação de Resultado de Ações Preventivas; Comportamento Sexual;HIV; Síndromeda Imunodeficiência Adquirida 
AIDS among children and youth in Brazil

Although there is considerable underreporting in Brazil relating to AIDS, other STDs, and drug abuse during adolescence, several studies have shown that initial sexual activity and experimentation with different psychoactive substances generally occurs between 10 and 19 years of age. As suggested by Santos (1996), despite the relatively small number of AIDS cases reported in Brazil in the 15-19year age bracket as of August 1995 (1,633), given the long incubation period, there signs that individuals diagnosed with AIDS at 20 to 29 years of were actually infected during adolescence, reinforcing the notion of vulnerability to STDs and drug abuse during this stage of life.

As of August 1998, a cumulative total of 140,362 AIDS cases had been reported in Brazil since 1980 (MS, 1998). The most significant HIV exposure category in people over 12 years of age was sexual contact (64\%). The vast majority of cases exposed to contaminated blood ( $12.9 \%$ of a total of $13 \%$ ) were intravenous drug users. Among individuals under 13, perinatal transmission accounted for $89.3 \%$ of infections. In the 15-24-year age group, 18,271 cases had been reported, corresponding to $13.1 \%$ of the cumul ative total, while the $25-39$ age group accounted for $59.7 \%$. Due to HIV's prolonged incubation period (approximately 8-10 years), one can conclude that a significant portion of infections occur in youth.

According to recent data from UNAIDS/ WHO (1998), new cases keep ap pearing at the same or increased rates in some countries, requiring further investment in prevention. According to UNAIDS/ WHO (1998), the number of people with HIV/Aids worldwide increased by $10 \%$ in 1998 . Half of the new infections occurred in individuals 15 to 24 years old.

Other data point to the occurrence of unprotected sexual activity among youth, as do the data on teenage pregnancy (under 19), which occurs in $13 \%$ of Brazilian females. According to data from the Ministry of Health (1996), $23.44 \%$ of the $2,821,211$ births assisted by the Unified Heal th System (SUS) in 1995 were in mothers 15-19 years of age. In Rio de Janeiro, $17 \%$ of live births in 1994 were in mothers from 12 to 19 years of age, or a total of 15,697 babies. Of these mothers, $60 \%$ were illiterate or had an incomplete primary education, reinforcing the association between sex-related behavioral vulnerability and gender and social factors, i.e., less access to schooling, information, and the ability to access and use contraceptive methods.
Demographic statistics on HIV transmission in the 1990s point to the increasing number of AIDS cases in women (of the 79,906 cases reported as of February 1996 in Brazil, 14,464 , or $18 \%$, were women). This has an increasing impact on the prevalence among children: $78.3 \%$ of pediatric AIDS cases resulted from vertical transmission. In addition, considering the increased mean survival time for people with AIDS due to combination therapy, many HIV-positive children are now in early adolescence and becoming sexually active, hence requiring safer sex/ prevention measures in their relationships.

\section{ZIG-ZAIDS: creating alternatives for HIV/Aids prevention}

The proposal to produce educational materials on HIV/ Aids prevention among youth began in 1988 , with the repercussions of the growing number of AIDS cases in the general population. Although the first cases were identified in homosexual males in the United States in 1981, due to homophobia and prejudice on the part of governmental institutions and segments of civil society both worldwide (Shilts, 1987) and in Brazil (Daniel \& Parker, 1991), there was unnecessary delay in formulating policies to stem the growth of the epidemic (Mann et al., 1993).

Controversy concerning the origin and transmission of the HIV and the lack of medicines and vaccines capable of reducing HIV transmission had contributed to a fatalist, prejudiced, and erroneous view of the disease. It was thus important to change the proposals so as to promote information that might encourage preventive practices. Around this time, an extensive survey conducted by Schall et al. (1987) on health issues among students included questions about elementary students' knowledge of AIDS. Answers by 365 students from two Brazilian cities, Rio de Janeiro (RJ) and Belo Horizonte, identified misconceptions, ignorance, and a fatalist view of the epidemic (Rebello et al., 1989). These data confirmed the importance of identifying educational approaches with contents capable of fostering preventive practices.

Meanwhile, an analysis of the literature, the media, and AIDS-related nongovernmental organizations pointed to the need for Brazilian educational materials focusing on HIV prevention among children and youth. In addition, information provided by public health departments and the media (Carrara \& Moraes, 1986) was al so fatalist and could hardly be viewed as 
educational. The overwhelming impression from AIDS prevention campaigns was that of a fatal disease. In the literature, research confirmed the results of our investigation with students as to the lack of information and widespread misconceptions (Pinho et al., 1989), besides highlighting the chal lenges of adopting preventive practices, given the complexity of issues involved in AIDS, like sexuality and death, which have always been taboo during childhood. The lack of dialogue on the issue stemmed from the exclusion of topics that neither family nor school found proper for children, maintaining a sort of traditional morality, hardly constructive or preventive. According to another prevailing notion, to speak about sex or drugs with children and youth might induce them to try drugs, if such issues were brought up outside the family, school, and health programs.

Since the advent of AIDS, society itself and the political power between the ideological repression of sexuality inside the family (once privatized by the social model) began to search for alternative pedagogical approaches to this question, observing the need for more communication and pressured by AIDS' potential risk to life and health. In short, both the survey among students and the literature analysis suggested the importance of creating pedagogical resources in the HIV/Aids prevention area to foster learning and debate about the epidemic's social and symbolic aspects.

The ZIG-ZAIDS game: theoretical basis and development

ZIG-ZAIDS was created in the context of a laboratory (the Health and Environmental Education Laboratory - LEAS - in the Biology Department at Instituto Oswal do Cruz/ Fundação Oswaldo Cruz - IOC/FIOCRUZ) focused on research and strategies to develop educational materials to promote disease prevention and health promotion from childhood onward. The research considers the need to stimulate dialogue and exchange of knowledge between adults and children, and among children themselves, considering such aspects as self-esteem, respect and responsibility towards one's own life and that of others as well as nature, and a commitment to improved quality of life. The starting point is an attempt to understand how children construct the meanings of health and disease in their own context, interacting with unique individual aspects such as self-esteem, prior experience, and family and school rela- tionships (Schall, 1996). In addition, the interviews and questionnaires provide a basis for obtaining better knowledge of the information level and appropriate language for the target population. A theoretical basis is essential to provide support for educational practices and new materials developed at LEAS.

Vygotsky $(1991,1993)$ underlies this current approach towards different processes of Ianguage constitution and concepts, considering children's spontaneous concepts towards the construction of scientific concepts. This is helpful in the construction of useful life skills. This approach is fostered by the game's own dynamics, in which misconceptions are replaced by a knowledge built collectively through conversation and cooperation. In developing the new materials, we considered what Vygostky proposes regarding the development of higher intellectual functions as the reflexive consciousness and deliberate control that, once added to the notion of the proximal development zone, might help parents and schools to overcome the requirements fixed solely to the hierarchy of mental age and to grasp the children's possibilities, considering the cooperation processes. A dialogical relation is added to the necessary cooperation among partners in the game as proposed by Bakhtin (1985), favoring an elaboration of meaning in health/ disease, making it possible to attain a complex meaning beyond the association limited to the biological body and achieving social and affective well-being, respect, and tolerance in human relationships. In addition, it promotes responsibility for environmental preservation, overcoming notions focusing only on immediate reality. Thus, scientific knowledge, once built, is not restricted to memorized definitions, rather health meanings are interlinked with other aspects of daily life, mixing unique points of view with collective perspectives consolidated by both cognitive and affective aspects (Schall, 1996).

It must also be emphasized that in the process of developing the ZIG-ZAIDS game the arguments described above were articulated as critical analyses of the limits of the current policies in the field of prevention that were based solely on biomedical information, individual responsibility, and/ or an alarmist and fatalist vision, as indicated in studies on HIV/ Aids prevention. Clearly prevention programs needed to consider the socioeconomic and political dimensions of the epidemic, as well as the diversity of the presentations and practices of the different social segments in relation to the disease (Homans \& Aggleton, 1988; Bolton, 1992; Ingham et al., 1992). 
This analytical perspective is linked to a given critical vision of education (Melo, 1993) that influences discussion of the educational nature of prevention work in the health field and consequently the development of materials. This focus is based on proposals by Freire (1979) on the role of education in social transformation, in which the former relates to the awareness-raising process characterized by permanent critical action by humans towards reality. Using this theoretical approach, this author questions pedagogical, domesticated actions centered on the educator's authority and knowledge and proposes a liberal concept of education, where educator and educated participate and collaborate in the learning process, in a relation using dialogue and problem-solving. This theoretical orientation introduces a political and social dimension to education, expanding the discussion of learning and analyzing the priority of the cognitive and emotional development of the person to be educated. This perspective is discussed by Monteiro (1995) and Paiva (1996) when planning HIV/ Aids prevention programs.

Based on these perspectives, the process of creating ZIG-ZAIDS was characterized by content selection and choice of the material's approach. We attempted to differentiate the content from the prevailing alarmist view of the epidemic, highlighting explanations identifying the possibility of safer sex practices, considering that sexual awareness takes place in pre-adolescence and adolescence, and that this requires sympathetic attitudes.

In relation to the approach, due to the target population's specificity, we tried to incorporate entertaining elements capable of motivating learning and stimulating thinking about the epidemic's social and symbolic aspects. We thus opted to create a question-and-answer game (which we named ZIG-ZAIDS), using accessible language and exploratory illustrations where the participants got information and would be motivated to talk about different scientific and social aspects of the epidemic.

ZIG-ZAIDS consists of a board with 23 numbered spaces and other spaces illustrated with a condom ("wild cards") and others with directions such as "go one space forward", "go one space backward", and "wait", two dice, six game pieces, 23 numbered question cards (with questions on one side and answers and directions for the next move on the other) and 20 wild cards. The question cards deal with subjects such as the immune system, transmission patterns, treatment, and prevention. The need for solidarity and cooperation in human relation- ships is emphasized. Unlike other games, three questions ask for opinions rather than right-orwrong answers. By asking about visits to AIDS patients, the importance of solidarity, and participation by children with HIV in school activities, the game creates opportunities for players to reflect on the social and psychological consequences of AIDS. The wild cards contain information on topics such as HIV, hemophilia, blood transfusions, drugs, job opportunities, new treatments, and other subjects relevant to people with HIV. ZIG-ZAIDS further contains a leaflet for parents and teachers, posing discussion questions on topics such as the difficulty and discomfort adults experience in discussing sex and the importance of listening to what children feel and think about sex. Also included are a mini-dictionary with words referring to sex organs, sexual relationships, and STDs. There is also a suggestion to include a condom as the first prize, and the recommendation that it be opened and shown to classmates.

In order to match the material to the target population's reality, the product was tested through an experiment including interviews before and after playing the game, in addition to direct observation. Using a test version of the game, we observed several episodes with elementary students from public and private schools in Rio de Janeiro. These episodes allowed us to verify the game's capacity to motivate learning and provides us with tips to alter and adjust it (Monteiro et al., 1990; Monteiro et al., 1991).

Based on the data from the test game, we developed the final version. At this stage, rules were changed, language adapted, and new contents included. We also evaluated the game's new visual layout, produced by experts. Besides testing the game with students, we also considered parents' and teachers' opinions. Interviews with the latter led to the production of a manual (included with the game) targeting parents and educators, with suggestions for additional reading, teaching activities, and addresses of governmental and nongovernmental institutions working with HIV prevention and/ or treatment for people with HIV/ Aids.

Once the final version of the material was developed, we attempted to identify publishers or companies that might be interested in producing the game on a commercial scale in order to market and distribute it. More detail on this stage of the methodology has been provided by Monteiro \& Rebello (1999).

The ZIG-ZAIDS game was developed from a research project applied to health education which also included training of human re- 
sources, since we felt that the game as an educational resource was complete, but did not replace teaching in practice. In this sense our commitment was not only to concentrate on the game's scientific impact, but al so to evaluate its impact in the search for partnerships that would foster access to its use, i.e., teaching institutions and health professionals involved in prevention education (Monteiro, 1998).

It is commonly felt that the production and evaluation of educational materials should be combined with training of human resources to augment the material's educational potential. We see the game as a teaching aid, and not as a replacement for educational activity. Based on the related literature on children (Schall, et al. 1987; Schall, 1996; 1999), entertaining educational aids like the ZI G-ZAIDS game (Monteiro et al ., 1991) and the Jogo da Onda game (or the “Wave Game") (Rebello \& Monteiro, 1998) focusing on drug prevention (Monteiro et al., 1994) can be seen to play an informative role and to serve as excellent instruments for initiating discussions and raising awareness on health-related issues.

The need to evaluate educational strategies

Evaluating an educational activity can assess previous and baseline measures in order to eval uate the change achieved. Evaluation can also be used to measure an educational proposal's feasi bility and reach, recording and analyzing its applicability to the proposed teaching situations.

Our evaluation aimed to verify the quality of intervention involved in the ZIG-ZAIDS game in various situations: from an initial situational analysis, which showed the need for educational material on STDs/ Aids targeting youth. The process thus incorporated elements from this situational evaluation, attempting to investigate the game's acceptability, followed by an evaluation of the process, considering the quality of the health education practice motivated by the game and stimulating different alternatives and in-depth consideration. It also included an impact evaluation on the efficacy in promoting knowledge-building and critical reflection concerning symbolic and social aspects of the AIDS epidemic among adolescents.

These levels of evaluation have been interpreted in different ways by various authors. Ayres (1996) makes an interesting analysis of the evaluation of educational intervention among students, related to the analysis of three principles: 1) realism, where the author leads the reader to conclude in favor of the relevance of evaluation criteria for real experience; 2) fecundity, highlighting the importance of "producing awareness of what is effectively being done" (Ayres, 1996:3) from a differentiation of the elements which determine the intervention's success; 3) practicability, expressed by the definition of objective methods that are accessible, motivating, and capable of producing significant data and likely to produce feedback. Through strategies described as examples, Ayres shows both the complexity and feasibility of constructing and conducting an evaluation process and thus offers important resources for evaluating educational interventions.

From a similar and complementary perspective, Aggleton (1995) discusses the evaluation of health education programs and attempts to differentiate between monitoring and evaluation, based on WHO definitions characterizing them as complementary actions. Planning these actions, in turn, involves the definition of themes to be investigated (e.g., cognitive and behavioral aspects and attitudes), as well as the indicators and methodological strategies to be used. This definition is based on the proposal's objectives, resources, and practicability. Due to this area's diversity and magnitude, Aggl eton highlights the limits and adequacy of three common evaluation strategies: the comparative approach, the approach on evaluation of objectives, and the interpretative approach (Aggleton, 1995:198-204), suggesting a general orientation for the questions.

\section{Methodology for evaluation} of ZIG-ZAIDS

Considering the educational material's methodological possibilities, the present study attempted to evaluate the ZI G-ZAIDS game's impact, establishing as a goal the analysis of its use and effectiveness, as a resource for motivation, learning, and preventive and non-discriminatory behaviors. We established complementary research methods, planned by the authors and conducted by Torres (1995), where the researcher was not involved in the previous phase, creating the game. The stages were as follows:

1) LEAS/FIOCRUZ file analysis, organized by the ZIG-ZAIDS authors on demands, defined as situational analysis. A list of questions were sent to people who ordered the game in order to help them to record their observations on the material. The leaflet sent to game users requested the following information: full name, 
profession, telephone, and address, and included questions such as:

- Where was the game played? (e.g. institution, community, business, school...)

- What was the age group of the players?

- What was the group's level of information about AIDS? How was the material received?

- Was the game presented within a program of AIDS prevention or sex education? Were any activities developed based on the material?

- Did the game reach its objectives as an educational tool? If necessary, please add your suggestions.

2) Opinions from the interviews and questionnaires filled out by game users, known as process analysis. The interviews done with the game users included the following questions:

- Name of institution where the game was played;

- What was the age group of the players?

- What was the players' level of information about AIDS?

- How was the material received?

- Was the game presented within a program on AIDS prevention or sex education?

- Are any other activities applied within this program? What are they?

- As an educator, did you feel prepared to use the material or was it necessary to consult other sources to better understand it? After the material was used, were other activities carried out to assess the assimilation of the information by the players? Did the game achieve its objectives as an educational tool?

The questionnaires were sent by mail to 42 schools and other institutions along with a letter. The letter explained the objectives of the evaluation process, as follows:

"We are conducting an evaluation on the impact of the educational game ZIG-ZAIDS here at the Environmental and Health Educati on Laboratory of the Oswal do Cruz Foundation. The game was developed by researchers from this institution within the educational component program of the Institutional AIDS program/FIOCRUZ, which is supported by the Division on Sexually Transmitted Diseases of the Brazilian Ministry of Health. The purpose of the game is to focus on the AIDS issuetogether with different groups from governmental and nongovernmental organizations, private companies, and schools, with a view towards providing basi c information on the disease to a broad public, especially children and adolescents.

To hel p achieve our objectives, we arecontacting professionals and institutions currently developing studies on preventive education in HIV/Aids. Knowing that you areinvolved in this field, we consider your collaboration to be of the utmost importance for the success of our study.

As a starting point, we would like to know whether you have access to the game or use it in any specific work? If so, we would ask you to answer the questionnaire below and return it to the ZIG-ZAIDS project as soon as possible.

1) How did you receive the game: through an institution or from some other source? How many sets did you receive?

2) Was the material distributed to schools or other institutionsthat work with AIDS?

3) Is therea follow-up system for the projects that are being carried out by the institutions that received the material?

4) Is theresomerecord of how the gameis being applied, to what age group, to what scholastic level and with what level of prior knowledge about AIDS?

Thanking you in advance for your cooperation,(...)"

3) Observation of ZIG-ZAIDS' use by preadolescents and adolescents, characterized as impact analysis. Efforts were made to combine quantitative evaluation (statistical analysis) and qualitative analysis, i.e., analysis of the opinions' content, interviews, direct observation, and photographic documentation. We also attempted to achieve an extensive regional sampling and diversity of the study population, attempting to include samples from a wide area of Brazil and from different situations in the game's use. The research was conducted within a diversified universe of professionals and institutions including public organizations, civil and private, national and international, beyond the fields of education and heal th. We thus attempted to verify the institutional and professional demands pertinent to requests for the game submitted to FIOCRUZ.

\section{Results}

Situational analysis: the game's acceptability

The first acceptability test refers to the market reaction itself on the occasion of the first edition in January 1991, in which 5,000 sets were released. Although part of this edition was purchased by institutions and companies, like the National office of the SESC (Serviço Social do Comércio) (1,000 sets), the publisher (Editora Salamandra, Rio de Janeiro) considered it a market failure. The market had not accepted the condom (included as a prize for game winner) or the "strong" language used in the minidictionary included with the game. Many large 
stores rejected the game, and this received extensive media coverage. This suggests that the public was not really prepared for a table game dealing with AIDS. Therefore, after an agreement with the authors, the manufacturer left the condom out of the subsequent editions, and its use was only a suggestion in the manual, to be purchased at the user's discretion. The publisher began using a distribution strategy emphasizing governmental and nongovernmental education and health institutions and companies promoting prevention programs with their workers. As a result, the publisher sold games to private businesses and various Secretaries of Education and Health around the country; the National STD/Aids Control Program purchased 100,000 sets to distribute to public schools and nongovernmental organizations.

The acceptability was also evaluated through questionnaires returned from 1991 to 1994, that had been attached to the sets donated by the Oswaldo Cruz Foundation to various groups and institutions (schools, health promoters, parents, companies, courses, communities, and others) from Brazil and abroad. Table 1 shows the items analyzed in a 20-questionnaire sample, including the name of the institution that used the game, opinions on ZIG-ZAIDS as an educational resource, target public, activities developed, other educational resources, place used, and general observations. Among the 20 institutions that answered the questionnaires, 10 were from Rio de Janeiro, four from São Paulo, and one each from Pernambuco, Minas Gerais, Mato Grosso do Sul, Rio Grande do Sul, Ethiopia, and Germany. The institutions included primary and secondary schools, health clinics, NGOs, boarding institutions for minors, and social and educational research institutes.

According to the data, the game was used in various situations: classrooms (primary and secondary), parents' meetings, women's groups, vocational courses, daycare centers, community health workers' supervision, companies' educational programs, courses for educational counselors, and meetings with psychologists, social workers, and other health professionals and educators. The information highlights the positive reaction to the material and its efficacy as an educational tool. In general the game was considered a good motivating factor, capable of generating interest and stimulating debates and learning about such controversial themes as sexuality and AIDS. The positive evaluation is certified by the quotes below:

"Excellent as an educational resource. Informs and stimulates reasoning about previous knowledge" (STDs Programs - Dourados/ MS 1995).

“Great! Discussing AIDS, sex, and drugs becameniceand educational" (Sociedade Diademense de Proteção ao Menor - 1995).

“After ZIG-ZAIDS,chil dren wrote letters to people with HIV (...) It became part of everyday life in the classroom, and besides teaching about AIDS, it reduced discrimination (CIEP Mestre André, Rio de Janeiro - 1995).

The possibility of discussing sexuality is presented in some reports as having been sparked by ZIG-ZAIDS within the group. The game was used by parents and teachers who often had not known how to cope with this subject among children and adolescents, as stated below:

"The game makes it possible to discuss AIDS naturally and without prejudice. AIDS is a disease that involves many issues that are still taboo and are often not discussed because of difficulties among teachers, parents and institutions. Theinitiative of producing the game was certainly very creative, a facilitating factor, and a great social contribution. (Municipal Secretary for Social Promotion, Nova Friburgo, Rio de Janeiro)

According to $50 \%$ of the 20 questionnaires, ZIG-ZAIDS was used together with other resources, in sex education programs which also included videos, lectures, debates, leaflets, and informative pamphlets. One of the points emphasized in the sample was the inclusion of social issues in the game, e.g., sympathy for and discrimination against children with AIDS, which has motivated debate among the youth who have used the material.

Some criticism was aimed at the repetition of questions, mainly by the kids with more knowledge about AIDS. The lack of a prize (the condom) for all players, or at least one for each classroom, the need for more difficult questions for older students (8th graders and high school). Some suggestions on the cards' content were useful for the second edition, as well as inclusion of themes in the wild cards set, in order to al ways include updated information in each new edition. Both international institutions, Mesganan Nega Addis Ababa (Ethiopia) and an institut from Berlin, Germany, highlighted the quality of the game, telling us about the lack of such materials in their countries. Since the cards had not been translated, they were not evaluated with the international target populations. In short, although commercial acceptability was initially jeopardized, we observed, through teaching, heal th surveys, and prevention institutions, that the material was not only well-received, it was also evaluated as 
Table 1

Examples of answers received on use of the game. Situational evaluation.

\begin{tabular}{|c|c|c|c|c|c|c|}
\hline $\begin{array}{l}\text { Name of } \\
\text { Institution }\end{array}$ & $\begin{array}{l}\mathrm{ZZ} \text { as an educational } \\
\text { resource }\end{array}$ & Target public & $\begin{array}{l}\text { Activities } \\
\text { developed }\end{array}$ & $\begin{array}{l}\text { Other educational } \\
\text { resources }\end{array}$ & Place used & Observations \\
\hline $\begin{array}{l}\text { Municipal Council } \\
\text { Três Pontas, MG }\end{array}$ & $\begin{array}{l}\text { Reaches its objectives. } \\
\text { While they are playing } \\
\text { people debate the } \\
\text { answers to the game } \\
\text { with the other } \\
\text { participants }\end{array}$ & $\begin{array}{l}\text { People aged } \\
12-50\end{array}$ & $\begin{array}{l}\text { Prevention work } \\
\text { during Carnaval } \\
\text { week. Tables were } \\
\text { set up in the square } \\
\text { where the general } \\
\text { public could } \\
\text { participate in the } \\
\text { game. Discussion } \\
\text { of ZZ questions and } \\
\text { answers }\end{array}$ & $\begin{array}{l}\text { Seminars, placards, } \\
\text { pamphlets. A TV } \\
\text { was installed to } \\
\text { show videos on } \\
\text { AIDS }\end{array}$ & $\begin{array}{l}\text { Community } \\
\text { institutions, } \\
\text { businesses, } \\
\text { and schools }\end{array}$ & \\
\hline $\begin{array}{l}\text { CEL - Lagoa } \\
\text { Educational } \\
\text { Center, RJ }\end{array}$ & $\begin{array}{l}\text { The game is good, } \\
\text { especially for } 6 \text { th and } \\
7 \text { th grade students } \\
\text { aged } 13 . \text { We felt that } \\
\text { it lacked more } \\
\text { controversial questions } \\
\text { suitable for 8th grade } \\
\text { students }\end{array}$ & $\begin{array}{l}\text { Students from } \\
6 \text { th-8th grades, } \\
\text { aged } 12-14\end{array}$ & $\begin{array}{l}\text { Sex education } \\
\text { program }\end{array}$ & $\begin{array}{l}\text { Raising questions } \\
\text { that reached the } \\
\text { public in a general } \\
\text { way }\end{array}$ & Schools & $\begin{array}{l}\text { Inadequate when } \\
\text { applied to the 8th } \\
\text { grade, considered } \\
\text { too immature, and } \\
\text { students did not take } \\
\text { advantage of the } \\
\text { game. There should } \\
\text { be more cards for } \\
\text { the } 8 \text { th and } 2 \text { nd } \\
\text { grades, allowing } \\
\text { greater flexibility } \\
\text { according to the } \\
\text { level of knowledge } \\
\text { of the working group }\end{array}$ \\
\hline $\begin{array}{l}\text { São Vicente State } \\
\text { High School 1st } \\
\text { and 2nd grades. } \\
\text { Irati, RJ }\end{array}$ & $\begin{array}{l}\text { The game generates } \\
\text { curiosity about other } \\
\text { topics related to AIDS } \\
\text { and sexuality } \\
\text { (...) In general it was } \\
\text { useful and the students } \\
\text { learned by playing. }\end{array}$ & $\begin{array}{l}\text { Students from } \\
5 \text { th-8th grades } \\
\text { and high school }\end{array}$ & & $\begin{array}{l}\text { Magazines and } \\
\text { newspapers with } \\
\text { news and updates } \\
\text { discussed in } \\
\text { seminars }\end{array}$ & High school & $\begin{array}{l}\text { One of the negative } \\
\text { points was the lack } \\
\text { of incentive for the } \\
\text { groups, prizes } \\
\text { consisting of only } \\
\text { three condoms }\end{array}$ \\
\hline $\begin{array}{l}\text { Sempre Viva } \\
\text { Program, RJ }\end{array}$ & $\begin{array}{l}\text { The youngsters } \\
\text { considered the game } \\
\text { an enjoyable } \\
\text { experience }\end{array}$ & $\begin{array}{l}\text { Young people } \\
\text { Aged 17-19, } \\
\text { girls who live } \\
\text { on the street }\end{array}$ & $\begin{array}{l}\text { Use of the game } \\
\text { was part of } \\
\text { constant process } \\
\text { of information } \\
\text { transfer and } \\
\text { incentive to use, } \\
\text { condoms seeking } \\
\text { the particular } \\
\text { expression of } \\
\text { the group in } \\
\text { developing action } \\
\text { tactics }\end{array}$ & $\begin{array}{l}\text { Program has as its } \\
\text { objectives a systematic } \\
\text { project for DST/AIDS } \\
\text { prevention and } \\
\text { awareness of wide- } \\
\text { ranging health concerns }\end{array}$ & $\begin{array}{l}\text { Sempre Viva } \\
\text { Program }\end{array}$ & $\begin{array}{l}\text { O ne of the girls in } \\
\text { the group asked that } \\
\text { the game be taken } \\
\text { into the streets to } \\
\text { allow the rest of her } \\
\text { group to play. There } \\
\text { is still no method of } \\
\text { evaluation for its use } \\
\text { among street people. }\end{array}$ \\
\hline $\begin{array}{l}\text { Cyanamid Química } \\
\text { do Brasil Ltd., RJ }\end{array}$ & $\begin{array}{l}\text { Immense potential to } \\
\text { reach the proposed } \\
\text { objectives, including } \\
\text { partnerships with } \\
\text { businesses for work } \\
\text { in schools and other } \\
\text { institutions }\end{array}$ & $\begin{array}{l}25-45 \text { year age } \\
\text { group }\end{array}$ & $\begin{array}{l}\text { The material was } \\
\text { applied only once } \\
\text { within SIPAT } \\
\text { (Internal Week for } \\
\text { the Prevention of } \\
\text { Accidents at Work) }\end{array}$ & $\begin{array}{l}\text { Seminars on AIDS with } \\
\text { orientation by company } \\
\text { physicians }\end{array}$ & Company & $\begin{array}{l}\text { The material was } \\
\text { received with } \\
\text { surprise, even with } \\
\text { reservations, but the } \\
\text { general reception } \\
\text { was very good. They } \\
\text { were expressions of } \\
\text { moral outrage (based } \\
\text { on false medical } \\
\text { perceptions) }\end{array}$ \\
\hline
\end{tabular}


adequate, necessary, and useful for the ongoing educational process.

The process analysis: the game's context and utilization

In order to complete the information obtained through the forms, we sent a standard letter containing a questionnaire, from February to April 1995, to 42 schools in different States, i.e., the ones which had received the game through the Health Ministry (the National STD/Aids Program. A standard questionnaire was also sent to several institutions and companies. We received answers from a total of 34 institutions. Data analysis, organized in a table, with the same contents described in the previous item (Table 2), reinforce the evaluations already mentioned and related to the game's effectiveness as a factor for educational motivation, as an easy-to-understand teaching tool. Although the game has been used by various groups, the majority were among adolescents from the 5th through 8th grades, with ages ranging from 10 to 16 years. Some examples of reports:

"ZI G-ZAI DS is what every stu dent needs to understand what is imagined not to be near him. If you givea book or lecture, $90 \%$ of them will remain silent" (Carla Jardim, rural area teacher in Bagé, Rio Grande do Sul, 1995).

"There has been great enthusi asm over the game among the kids. The creativeapproach to AIDS was emphasized and theopportunity that the gameoffers to discuss ample questi ons, such as social aspects, prejudice, and solidarity" (Antônio Teixeira, Director, Labor Relations Department, Brazilian Postal Company, 1995).

This analysis also considered the ZIG-ZAIDS evaluation addressed to the National STD/Aids Control Program. As of March, 1995, 10 months after the purchase, $25 \%$ of the sets $(25,000)$ had been distributed. Of the 27 letters sent by Torres to the State health and educational departments that received the material, only 5 replied. Among these, 4 had received a larger number of sets and distributed them to schools to integrate them into the prevention program. In order to complete this analysis, Torres interviewed the people responsible for distributing the material.

Considering the 54 institutions which represent the total number of questionnaires sent to LEAS ( 1991 to 1994) and to Torres in 1995, $84.2 \%$ state that the objectives of the game have been "fully reached"; $3.70 \%$ say "satisfactorily", and $1.7 \%$ "reasonably well". Nobody noted "a little", and $9.3 \%$ failed to answer this question.
Impact analysis: observations

on use of the game

This analysis is based on direct observations of the game matches with kids from 11 to 17 years of age from two private schools and the Instituto de Ação Cultural (Cultural Action Institute), by which we observed that students construct new cognitive elements by playing the game. Filled with excitement, the game's content is grasped easily, besides initiating debates and explanations on the topic. One teacher commented, "Wenoticed that even thechildren who knew the material got involved in the activity" (1995). Competition stimulates learning while playing, making it right to win and paying attention to the right answers so as not to make mistakes again. However, the question's repetition as a consequence of the game's dynamics was criticized by the more informed students. Some young people's opinions:

"ZIG-ZAIDS is perfect. If it were any better, it would be worse" (1995).

"I would like to know more things not informed by the game" (1995).

"I havelearned to not be prejudiced towards peoplewith HIV. They deserveall our careand attention" (1995).

"If I were you, I would manufacture more games to distribute them all over the world" (1995).

Torres also organized the comments by some professionals involved in the testing of ZIG-ZAIDS. In general, the game was considered a teaching resource capable of approaching a controversial theme in an entertaining and efficient way. According to suggestions, its use should be strengthened by educators' actions in the sense of delving more deeply and/ or adapting the contents to different realities. The few criticisms towards certain contents and the material's dynamics were all documented by the authors and turned into improvements in the game, including the proposal for an expanded version on CD-ROM, containing 6 levels of difficulty, making it possible to provide choices by age and previous knowledge. This allows for the acquisition of scientifically advanced and complex knowledge according to the user's curiosity and cognitive capacity.

A second experience was reported by the Paraná State Departments of Education and Health, which used the game integrated into a prevention program developed in several schools and health centers around the State. The program aimed at improving drug abuse and STD/Aids prevention. During June 1996 the game was used with 3,345 adolescents from 
Table 2

Examples of answers received from 34 institutions. Process analysis.

\begin{tabular}{lll}
\hline $\begin{array}{l}\text { Name of } \\
\text { Institution }\end{array}$ & $\begin{array}{l}\text { ZZ as an educational } \\
\text { resource }\end{array}$ & Target public \\
\hline $\begin{array}{l}\text { Mesganan Nega } \\
\text { AIDS Control }\end{array}$ & $\begin{array}{l}\text { Allows young people } \\
\text { to relax while }\end{array}$ & $\begin{array}{l}\text { General public } \\
\text { in the country }\end{array}$ \\
Ababram, Addis & $\begin{array}{l}\text { transmitting knowledge } \\
\text { about HIV/Aids. }\end{array}$ & \\
& $\begin{array}{l}\text { Recommendable for } \\
\text { teaching young people } \\
\text { and their parents }\end{array}$
\end{tabular}

$\begin{array}{ll}\text { Activities } & \text { Other educational } \\ \text { developed } & \text { resources }\end{array}$

Place of
application

Leaflets, posters, films,

Difficulties were

and dramatizations

encountered in using

the material because

of language

problems: when

letter was answered

the game was being

translated. The

impression is general

based on the figures.

There is no material

available on AIDS

presented in the

form of a game in

this country

\begin{tabular}{lll}
\hline CIEP - Mestre & Treats a controversial & Elementary \\
Andre, Padre & issue in an & $\begin{array}{l}\text { The game was used } \\
\text { students, aged } \\
\text { Miguel, RJ }\end{array}$ \\
entertaining way & $8-13$ & $\begin{array}{l}\text { competition. Later } \\
\text { it was used as }\end{array}$ \\
& & $\begin{array}{l}\text { a learning tool } \\
\text { requested by }\end{array}$ \\
& & students
\end{tabular}

\begin{tabular}{llll}
\hline $\begin{array}{l}\text { Federal Technical } \\
\text { College of }\end{array}$ & $\begin{array}{l}\text { Valid. Motivates the } \\
\text { adolescent to know } \\
\text { Pernambuco, PE }\end{array}$ & $\begin{array}{l}\text { Team of } \\
\text { teachers, health }\end{array}$ & $\begin{array}{l}\text { Parents' meeting. } \\
\text { the danger and }\end{array}$ \\
$\begin{array}{lll}\text { understand the AIDS with } \\
\text { issue }\end{array}$ & $\begin{array}{l}\text { professionals, } \\
\text { social workers, ineducational } \\
\text { psychologist, }\end{array}$ & $\begin{array}{l}\text { orientation. Debate } \\
\text { parents, and } \\
\text { students }\end{array}$ & $\begin{array}{l}\text { and analysis with } \\
\text { AIDS study group }\end{array}$
\end{tabular}

Videos and seminars Technical We would only with doctors. Debates College and question the answer and analyses with AIDS Clinical Hospital to the question on study group

hemophiliacs, which defines them as people who have difficulty in forming scars. Shouldn't it be "difficulty in blood clotting"?

\begin{tabular}{|c|c|c|c|c|c|c|}
\hline $\begin{array}{l}\text { Municipal Council } \\
\text { Novo Friburgo, RJ }\end{array}$ & $\begin{array}{l}\text { Approaches AIDS in } \\
\text { a natural way, without } \\
\text { prejudice. }\end{array}$ & $\begin{array}{l}\text { Students, } \\
\text { teachers and } \\
\text { the community } \\
\text { in general }\end{array}$ & $\begin{array}{l}\text { Activities to prevent } \\
\text { AIDS and drug use } \\
\text { - talks for teachers, } \\
\text { students and } \\
\text { Parents. Warnings } \\
\text { to the community. }\end{array}$ & $\begin{array}{l}\text { Announcements, } \\
\text { Videos, pamphlets, } \\
\text { games, and books that } \\
\text { discuss sex education }\end{array}$ & $\begin{array}{l}\text { Community, } \\
\text { schools of the } \\
\text { public, state } \\
\text { and private } \\
\text { networks }\end{array}$ & $\begin{array}{l}\text { In the talks I try to } \\
\text { get across the need } \\
\text { to inform people, } \\
\text { while showing the } \\
\text { resources available, } \\
\text { to facilitate the work } \\
\text { of people who come } \\
\text { forward offering to } \\
\text { be multipliers of } \\
\text { information on AIDS } \\
\text { prevention }\end{array}$ \\
\hline
\end{tabular}

\begin{tabular}{|c|c|c|c|c|c|}
\hline $\begin{array}{l}\text { Health Center, } \\
\text { J uquiá, SP }\end{array}$ & $\begin{array}{l}\text { Clear, objective } \\
\text { questions. Stimulates } \\
\text { interest in learning } \\
\text { through play. }\end{array}$ & $\begin{array}{l}\text { Students aged } \\
13-15\end{array}$ & $\begin{array}{l}\text { Integral health care } \\
\text { for the adolescent } \\
\text { project. The game } \\
\text { was presented on } \\
\text { a day when AIDS } \\
\text { was the theme. }\end{array}$ & $\begin{array}{l}\text { Weekly meetings to } \\
\text { discuss themes of } \\
\text { public interest. }\end{array}$ & $\begin{array}{l}\text { Center for } \\
\text { living Together } \\
\text { with the Ill. } \\
\text { Public building. }\end{array}$ \\
\hline $\begin{array}{l}\text { Dourados } \\
\text { DST/AIDS }\end{array}$ & $\begin{array}{l}\text { Excellent as an } \\
\text { educational resource. } \\
\text { Informs and stimulates } \\
\text { reasoning about } \\
\text { previous knowledge. }\end{array}$ & $\begin{array}{l}\text { Members of } \\
\text { the team and } \\
\text { students of the } \\
2 \text { nd grade and } \\
\text { outside school. }\end{array}$ & & $\begin{array}{l}\text { Information leaflets, } \\
\text { videotapes, talks to } \\
\text { adolescents. }\end{array}$ & $\begin{array}{l}\text { Schools and } \\
\text { evening classes. }\end{array}$ \\
\hline
\end{tabular}


primary and secondary schools under the orientation of 223 supervisors trained to develop preventive activities with young people and their teachers. The report describes three experiences at different levels: one with 7th and 8th grade students, another with 5th to 8th grade students, and a third with first-year secondary school students. Observations by supervisors and teachers highlight the game's ability to stimulate the learning process in a highly entertaining way. Some important comments:

"The game provides valuable information, which is passed on to thestudents in a light and natural form."

"The same question is asked several times, emphasizing the essential points on thetopic of AIDS."

“I was impressed by the students' enthusiasm and their dedication in reading and answering the questions, to the extent of memorizing the right answers. The interest in winning the prize (a condom) was most notable in 5th gradestudents, who would find it more difficult to obtain prophylacticsunder normal circumstances."

"I'm going to order more sets, at the insistence of my students. This is a very positive way to talk about a very daunting subject. I myself had a cousin who died as a consequence of AIDS in July 1995..."

Some teachers commented that in spite of the fact that repetition of the cards hel ps memorize the correct answers, “they didn't li ke this process of repetition, preferring to move on to new questions". Several teachers said that the students wanted more questions to enrich the game and give it more variation, increasing its interest and catering to different levels of curiosity. Although the older, more advanced students agreed that the game was an interesting way of dealing with the matter, facilitating dialogue on sexuality which they felt is still somewhat repressed even today, they found some questions too easy for students in the second year of high school. This is natural, since the game was created for pre-adolescents (9-12 years old). However, comments by these older students illustrate the need to create versions with increasing levels of complexity and depth of knowledge.

\section{Discussion}

Based on the results collected at each different stage of evaluation, we concluded that the population's information level is more relevant to the game's impact than age. Another aspect relates to the diversity of ZIG-ZAIDS' use. The game was applied to health and educational professional training, in activities with street girls, in municipal events like one in Três Pontas (Minas Gerais State), where it was played on tables in the town square during Carnival, besides other activities in schools, companies, and communities. At the health center in $\mathrm{Mi}$ guel Pereira (Rio de Janeiro State), the game board was turned into a canvas; at the Colégio Bandeirantes in the city of São Paulo the game was reproduced on overhead transparencies so that all the students could take part in some observations.

Finally, after months of contact with professionals and students that have used the game in several parts of the country, Torres remarks that "ZIG-ZAIDS is an intelligent and appropriate alternative, because it provides information about AIDS in a playful, creative, and innovative way. Since the game is fun to play, it decreases any probable embarrassment (...) and allows for in-depth questions concerning sexuality" (Torres, 1995:51). In practice, repetition of the cards was considered negative; although the goal was to help memorize the information, the players generally tended to get tired and just go ahead. Nevertheless, the game was considered an effective, informative resource. Its use was associated with complementary teaching activities, to adapt its language to the population with reading difficulties and the content expanded for groups with better information.

The results of this study, besides complementing and expanding previous evaluations on the game's reach in different contexts, offer suggestions to strengthen the game's use and data capable of guiding new material production in this field, such as the ongoing CD-ROM. In other words, we see the evaluation process as a fundamental resource for the comprehension of the objectives and reach of an educational proposal. From this process we can reformulate and/ or reproduce our actions.

This is important to reinforce the game's role as a facilitator for conversations about sexuality either at school or at home. Only recentIy have Brazilian schools begun to prepare for the challenge of achieving full education in which sexuality is approached by associating cognition, affection, and social values in order to build citizenship. It is in this field of socialization in the school where children now often spend more time than at home, where many values and cognitions are reinforced and constituted, where attitudes are molded and decisions about the human future are outlined. This is the scenario in which children and ado- 
lescents meet their partners and rehearse their love lives. Despite theoretical advances in psychology and pedagogy, educational practice is still characterized by emphasis on transmission of contents which are not al ways useful to students in life. Nevertheless, in classroom, beyond the formal subject, there is another context happening which is characterized by a scheme of relations and hidden conflicts with the busy teacher and which can be made explicit if alternatives are created for their expression, and games like ZIG-ZAIDS could be useful in this sense.

Although aware of the limited knowledge concerning behavior change, we have here the greatest challenge for educational activity. As Rosenstock (1990) states, knowledge is important, sometimes essential for behavior change, but it is rarely enough. It is in the unknown world of reason that people are driven to behave in one way and not in another, where one finds health and disease, happiness and grief, and success and failure, amongst other phenomena. Thus, the educational process must be integrated with affect in order to begin the necessary changes. The mere acquisition of knowledge is not enough to engender the attitudes and actions that are the very goal of educational initiatives in the health area.

Materials like ZIG-ZAIDS are certainly facilitators of this process, which requires enabling of educators to achieve its goals, along with orientation and evaluation of its effectiveness, comparing the strategies' variations and contexts of the current work. Schall (1996) already reported that health-related knowledge expresses that children place value on themselves as healthy and reveals the meaning and values they ascribe to this fundamental aspect of their lives. Thus, it also reveals each child's identity, his/her perceptions, experiences, motivations, and actions expressing an image of oneself, making it possible for them to work beyond physical and cognitive aspects.

It is believed that in relation to STD/Aids and drugs, it is necessary to go beyond both traditional practices of knowledge transmission and a climate of threats to consider a longterm intervention begun in pre-school. This would be capable of strengthening children and adolescents in order for them to not only better understand themselves but to also practice community activities that stimulate respect and responsibility for themselves and others. This is necessary for children from an early age to not accommodate themselves to unbalanced and unfair social situations, to enable them to make choices, without feelingembarrassed by the group, and to achieve better human relations and better communications and empathy through an educational process in which families and schools interact.

\section{Acknowledgement}

The authors are greatly indebted to Dr. Michael Ross (School of Public Health, University of Texas) for his critical review and valuable comments. They are also grateful to Mr. Geraldo Jordão (Salamandra Editions), the publisher of the game, for his very important support.

\section{References}

AGGLETON, P., 1995. Monitoramento e avaliação de educação em saúde e promoção da saúde voltados para o HIV/Aids. In: AIDS Pesquisa Social e Educação (D. Czeresnia, E. M. Santos, R. Barbosa \& S. Monteiro, org.), pp. 193-206, São Paulo: Editora Hucitec/Rio de Janeiro: Abrasco.

AYRES, J. R., 1996. Como Avaliar uma Intervenção? Secretaria do Estado da Educação - Fundação para o Desenvolvimento da Educação. (mimeo.)

BAKHTIN, M., 1985. Estética de la Creácion Verbal. Buenos Aires: Siglo Veintiuno Argentina Editores.

BOLTON, R., 1992. AIDS and promiscuity: Muddles in the models of HIV prevention. Medical Anthropology, 14:145-223.

CARRARA, S. \& MORAES, C., 1986. Um mal de folhetim. Caderno do IMS/UERJ, 1:79-94.

DANIEL, H. \& PARKER, R., 1991. AIDS, a Terceira Epidemia. São Paulo: Iglu.

FREIRE, P., 1979. Conscientização, Teoria e Prática da Libertação. São Paulo: Cortez e Moraes. 
HOMANS, H. \& AGGLETON, P., 1988. Health education, HIV infection and AIDS. In: Social Aspects of AIDS (P. Aggleton \& H. Homans, eds.), pp. 12351242, London: The Falmer Press.

INGHAM, R; WOODCOCK \& STENNER, K., 1992. The limitations of rational decision-making models as applied to young people's sexual behavior. In: AIDS: Rights, Risk and Reason (P. Aggleton, P. Davies \& G. Hart, eds.), pp. 163-173, London: The Falmer Press.

MANN, J.; TARANTOLA, D. J. M. \& NETTER, T. W., 1993. A AIDS no Mundo. Rio de Janeiro: Associação Brasileira Interdisciplinar de AIDS/Instituto de Medicina Social, Universidade do Estado do Rio de Janeiro/Editora Relume-Dumará.

MELO, J. C., 1993. Educação: Razão e Paixão. Rio de Janeiro: Escola Nacional de Saúde Pública, Fundação Oswaldo Cruz.

MONTEIRO, S., 1995. A AIDS no Contexto Escolar: Análise de um Programa de Prevenção. Dissertação de Mestrado. Rio de Janeiro: Instituto de Medicina Social, Universidade do Estado do Rio de Janeiro.

MONTEIRO, S., 1998. AIDS prevention in Brazilian public schools: A partnership between governments and a nongovernmental organization. Ciência eCultura, 50:319-328.

MONTEIRO, S. \& REBELLO, S., 1999. Desenvolvimento e avaliação de jogos educativos no campo da prevenção do HIV/Aids e do uso indevido de drogas. In: Drogas e AIDS: Questões de Direitos Humanos (G. Acselrad, org.), Rio de Janeiro: Editora Fiocruz (no prelo).

MONTEIRO, S.; REBELLO, S. \& SCHALL, V. T., 1990. Desenvolvimento e Avaliação do Jogo Educativo sobre a AIDS para Pré-adolescentes, Pré-teste e Aperfei çoamernto. 42a Reunião Anual da SBPC Sociedade Brasileira para o Progresso da Ciência, Anais, Vol 2, Porto Alegre: SBPC.

MONTEIRO, S.; REBELLO, S. \& SCHALL, V. T., 1991. An educational game about AIDS for children. Hygie: International Journal of Health Education, 10:32-35.

MONTEIRO, S.; REBELLO, S. \& SCHALL, V. T., 1994. Jogan do e aprendendo a viver: Uma abordagem da AIDS e das drogas através de recursos educativos. In: Drogas eAIDS: Estratégi as de Redução de Danos (F. Mesquita \& F. Bastos, org.), pp. 133-146, São Paulo: Editora Hucitec/IEPAS.

MS (Ministério da Saúde), 1998. AIDS: Boletim Epidemiológi co, Ano XI, Número 3. Programa Nacional de DST/Aids.

PAIVA, V., 1996. Fazendo Arte com a Camisinha: A História de um Projeto de Prevenção da AIDS para Jovens. Tese de Doutorado, São Paulo: Instituto de Psicologia, Universidade de São Paulo.

PINHO, J. B.; AOKI, F. H.; LIMA, J. N.; ABREU, W. B.; PAVAN, M. H. P.; MONTEIRO, D. T.; DIAS, M. B. G. S.; PEDRO, R. J.; SILVA, L. A. M. \& EUGÊNIO, C. M., 1989. Avaliação do nível de informação sobre AIDS na população de Campinas, SP. In: XX Congresso da Sociedade Brasileira de Medicina Tropical, Anais, p. 153. São Paulo: Sociedade Brasileira de Medicina Tropical.
REBELLO, S. M.; MONTEIRO, S.; SCHALL, V.T.; MOREIRA, M.; PINTO DIAS, A. \& SANTOS, M.G., 1989. Conheci mento da AIDS entre Crianças e Pré-adoIescentes: Um Estudo Amostral do Ri o de Janeiro e Bel o Horizonte. 41a Reunião Anual da Sociedade Brasileira para o Progresso da Ciência - SBPC, Anais, Fortaleza: SBPC.

REBELLO, S. M . \& MONTEIRO, S., 1998. O Jogo da Onda. Rio de Janeiro: Edições Consultor.

ROSENSTOCK, I. M., 1990. The past, present, and future of health education. In: Health Behavior and Health Education (K. Glanz, F. M. Lewis \& B. K. Rimer, eds.), pp. 405-420, San Francisco: JosseyBass Publishers.

SANTOS, E. M., 1996. Em que um companheiro crítico pode contribuir. In: AIDS Educação: Um Conviteà Prevenção (C. Castello Branco, E. M. Santos $\&$ S. Monteiro, org.), pp. 10-15, Rio de Janeiro: Associação Brasileira Interdisciplinar de AIDS.

SCHALL, V. T., 1996. Saúdee Afeti vi dade na Infância: O que as Crianças Revel am e a sua Importância na Escola. Tese de Doutorado, Rio de Janeiro: Departamento de Educação, Pontifícia Universidade Católica do Rio de Janeiro.

SCH ALL, V. T., 1999. A prevenção de DSTs/ Aids e do uso indevido de drogas a partir da infância e da adolescência: Uma abordagem lúdico-afetiva. In: Drogas e AIDS (G. Acserald, org.), Rio de Janeiro: Editora Fiocruz (no prelo).

SCHALL, V. T.; JUBERG, P.; BORUCHOVITCH, E.; FÉLIX-SOUSA, I. C.; ROZEMBERG, B. \&VASCONCELLOS, M. C., 1987. Health education for children, developing a new strategy. In: Second International Seminar on Misconceptions and Educational Strategies in Science and M athematics, Abstracts. New York: Cornell University.

SHILTS, R., 1987. And the Band Played on, Peopleand theAIDS Epidemic. New York: St. Martin's.

TORRES, M., 1995. ZIG-ZAIDS, Avaliação dos Impactos. Relatório de pesquisa. Rio de Janeiro: Laboratório de Educação em Ambiente e Saúde, Departamento de Biologia, Instituto Oswaldo Cruz, Fundação Oswaldo Cruz. (mimeo.)

UNAIDS/WHO (Joint United Nations Programme on HIV/ Aids/ World Health Organization), 1998. Report available on the internet - World AIDS Day Statement by Dr. George Alleyne, Pan American Health Organization, Washington, November 30 (Received by e-mail: opas-comunica@bra3.opas. org.br)

VYGOTSKY, L. S., 1991. A Formação Social da Mente. São Paulo: Martins Fontes.

VYGOTSKY, L. S., 1993. Pensamento e Linguagem. São Paulo: Martins Fontes. 